\title{
Comparative study about the performance of three types of modified natural treatment systems
} for rice noodle wastewater

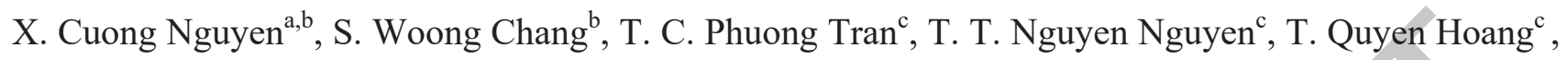
J. Rajesh Banu ${ }^{\text {d, }}$ Ala'a Hamed Al-Muhtaseb ${ }^{\mathrm{e}}$, D. Duc La ${ }^{\mathrm{f}}$, Wenshan Guo ${ }^{\mathrm{g}}$, Huu Hao Ngo ${ }^{\mathrm{g}}$, and Dinh Duc Nguyen ${ }^{\mathrm{h}, \mathrm{i}, \mathrm{j}, *}$

${ }^{a}$ Center for Advanced Chemistry, Institute of Research and Development, Duy Tan University, 03 Quang Trung, Da Nang, Vietnam.

${ }^{b}$ Department of Environmental \& Energy Engineering, Kyonggi University, Republic of Korea.

${ }^{\mathrm{c}}$ Faculty of Environmental Engineering Technology, Hue University - Quang Tri Campus, Vietnam.

${ }^{d}$ Department of Civil Engineering, Anna University Regional Campus, Tirunelveli, Tamilnadu, India

${ }^{\mathrm{e}}$ Petroleum and Chemical Engineering Department, Faculty of Engineering, Sultan Qaboos University, Oman.

${ }^{\mathrm{f}}$ School of Science, RMIT University, GPO Box 2476, Melbourne, Australia.

${ }^{g}$ Centre for Technology in Water and Wastewater, School of Civil and Environmental Engineering, University of Technology Sydney, Sydney, NSW 2007, Australia.

${ }^{\mathrm{h}}$ Department for Management of Science and Technology Development, Ho Chi Minh City, Vietnam.

${ }^{i}$ Faculty of Environment and Labour Safety, Ho Chi Minh City, Vietnam.

${ }^{j}$ Department of Environmental Energy Engineering, Kyonggi University, Suwon, Korea.

Revised Manuscript Submitted to

Bioresource Technology

31 January 2019

*Corresponding author:

nguyensyduc@gmail.com (D. Duc Nguyen) 


\section{Abstract}

In this study, three semi-pilot scale systems (vertical flow constructed wetland, multi-soil layering, and integrated hybrid systems) for treating real rice noodle wastewater were operated parallelly for the first time in a tropical climate at a loading rate of $50 \mathrm{~L} /\left(\mathrm{m}^{2} \cdot \mathrm{d}\right)$ for more than 7 months to determine the optimal conditions and to compare their treatment performance. The results demonstrated that these systems were appropriate for the removal of organics, suspended solids, and total coliform (Tcol). The highest reductions in chemical oxygen demand $\left(\mathrm{COD}_{\mathrm{Cr}}, 73.2 \%\right)$, phosphorus $\left(\mathrm{PO}_{4}-\mathrm{P}, 54 \%\right)$, and Tcol (4.78 $\log$ MPN/100 mL inactivation) were obtained by the integrated hybrid system, while the highest removal efficiencies of ammonium $\left(\mathrm{NH}_{4}-\mathrm{N}, 60.64 \%\right)$ and suspended solids $(80.49 \%)$ were achieved in the vertical-flow-constructed wetland and multi-soil layering systems respectively.

Keywords: constructed wetland; multi-soil layers; rice noodle wastewater; decentralized wastewater treatment system. 


\section{Introduction}

Untreated or incompletely treated wastewaters from the rice noodle villages in central Vietnam have been of great concern because they pose a serious impact on community health and ecological functions (MONRE, 2008). The production process of rice noodles releases a large volume of wastewater containing high concentrations of complex organic and nutrient compounds and high $\mathrm{C} / \mathrm{N}$ ratios (Karmee, 2018; Siripattanakul-Ratpukdi, 2012; Suwan et al., 2014). The biggest challenge regarding a handicraft village wastewater is not only the technological solutions but also the costs of the treatment. Despite the significant advances in wastewater treatment technology, low-cost natural wastewater treatment methods have attracted more attention in recent years, especially in low and middle-income countries. These technologies are considered feasible tools for addressing the wastewater contamination in traditional handicraft villages, where centralized wastewater treatment plants might be impractical due to the high cost of construction, maintenance, and operation (Tang et al., 2019). Among the natural- wastewater treatment systems (WWTS), two types have generated considerable research interest: constructed wetland (CW) (Corbella et al., 2017; Luo et al., 2014; Marzo et al., 2018; Sgroi et al., 2018) and multi-soil layering (MSL) systems (Latrach et al., 2018; Shen et al., 2018; Song et al., 2018). Technically, both are designed based on mimicking natural processes, including filtration, adsorption, plant uptake, volatilization, and microbial degradation precipitation, in a controlled manner to neutralize pollutants in wastewater and enhance microbial activity in packed or filled beds (Jia et al., 2018; Luanmanee et al., 2001; Wei \& Wu, 2018). The components and filter materials (sand, gravel, charcoal, zeolite, rice straw, soil, biochar, metal, and plants) constituting these systems are usually locally available and inexpensive (Ho and Wang, 2015). In addition, they are easily constructed and require simple operation and maintenance (Ho and Wang, 2015; Li et al., 2017). 
Many studies have investigated CW (Uggetti et al., 2016; Valipour and Ahn, 2015; Vo et al., 2018; Vymazal, 2005; Wu et al., 2015) and MSL (Chen et al., 2009; Guan et al., 2015; Guan et al., 2018; Masunaga et al., 2007) for the removal of suspended solids, organic matter, nutrients, pathogens, and metals from various kinds of common wastewater (sewage, domestic wastewater, grey-water, river water, etc.) and have achieved a satisfactory removal performance (Bonanno et al., 2018; Licciardello et al., 2018). Recently, a study of Koottatepand co-workers (2018) integrated CW with MSL for treating septic tank effluent and called it novel multi-soil layer constructed wetland. However, there are currently very few or no reports comparing the effectiveness of these technologies in a similar context. In particular, no information is available on the evaluation and comparison of these technologies for rice noodle wastewater treatment (RNWWT) to date. Therefore, the comparison of data between studies with different experimental and operational conditions is often unsuitable and may lead to incorrect conclusions. For example, several studies concluded that MSL has more advantages and higher removal efficiency of pollutants than the other systems in terms of percentage, mass loading rate, and hydraulic loading rate (HLR) (Guan et al., 2012; Wakatsuki et al., 1993). However the application of MSL in practice is a less utilized method (Guan et al., 2012). Therefore, it is necessary to investigate these gaps about WWTS.

In this scenario, three semi-pilot scale systems, namely a vertical flow constructed wetland (VF-CW), MSL system, and integrated hybrid (IH) system, were parallel operated for a long period of time to compare their treatment efficiency for treating the wastewater from the rice noodle village under the same conditions of configuration in terms of size (height and volume), plants, and operational parameters. This experiment is also the first attempt to use of VF-CW, MSL, and IH systems for RNWWT. Furthermore, a parallel comparison at the same condition contributes to limit the bias in assessing WWTS which previous researches have done separately. 
The specific objectives of this study were to determine optimal operating parameters and to evaluate and compare the performance of the VF-CW, MSL, and IH systems. Therefore, the results obtained could be used to plan appropriate technologies for treating rice noodle wastewater, which could allow greater versatility in choice of technology, design, installation, and operation to treat wastewater.

\section{Materials and methods}

\subsection{Raw wastewater}

The rice noodle wastewater used to feed the experimental systems in this study was randomly collected from a storage tank of a household producer in Cam Thach traditional noodle handicraft village, Cam Lo District, Quang Tri Province, north-center Vietnam. The wastewater obtained from the storage tank was pre-treated in a septic tank biogas basin. The characteristics of the rice noodle wastewater used in this study and effluent discharge requirements are depicted in Table 1.

Table 1. Characteristics of raw wastewater used in this study $(n=36)$.

\begin{tabular}{lccccccccc}
\hline \multirow{2}{*}{ Parameter } & \multirow{2}{*}{ Units } & \multicolumn{7}{c}{ Rice noodle wastewater quality } & \multirow{2}{*}{ Vietnam's standard* } \\
\cline { 3 - 7 } & & Mean & \pm & $\mathrm{SD}$ & & Min & - & Max & \\
\hline $\mathrm{COD}_{\mathrm{Cr}}$ & $\mathrm{mg} / 1$ & 338.61 & \pm & 114.83 & 197.50 & - & 766.25 & 150 \\
$\mathrm{NH}_{4}-\mathrm{N}$ & $\mathrm{mg} / 1$ & 72.10 & \pm & 30.95 & 24.55 & - & 135.35 & 10 \\
$\mathrm{NO}_{3}-\mathrm{N}$ & $\mathrm{mg} / 1$ & 0.44 & \pm & 0.57 & 0.11 & - & 2.54 & 50 \\
$\mathrm{PO}_{4}-\mathrm{P}$ & $\mathrm{mg} / 1$ & 16.70 & \pm & 3.25 & 8.56 & - & 24.20 & 10 \\
$\mathrm{TSS}$ & $\mathrm{mg} / 1$ & 87.27 & \pm & 21.41 & 37.60 & - & 132.00 & 100 \\
$\mathrm{Tcol}$ & $\mathrm{MPN} / 100 \mathrm{ml}$ & 78.547 & \pm & 30.373 & 34.300 & - & 12.940 & 5.000 \\
$\mathrm{pH}$ & - & 7.29 & \pm & 0.11 & 7.02 & - & 7.45 & $5.5-9$ \\
\hline
\end{tabular}

SD: Standard deviation

*Vietnam's standard includes the National Technical Regulation on Domestic Wastewater (QCVN 14:2008BTNMT) and Industrial Wastewater (QCVN 40:2011/BTNMT). 


\subsection{Experimental setup and description}

Three parallel experimental systems were set up in similar rectangular steel tanks that were protected by double layer epoxy coating (Supplementary material). All three tanks were the same size with dimensions of $0.6 \mathrm{~m}$ in length (L), $0.4 \mathrm{~m}$ in width (W), and $0.6 \mathrm{~m}$ in height $(\mathrm{H})$. Then, the systems were constructed and filled with bed media with different levels, sizes, and densities and marked as the VF-CW system, MSL system, and IH system respectively. The VF-CW system consisted of three layers of $10 \mathrm{~cm}$ of coarse gravel $(3-5 \mathrm{~cm}$ in diameter) at the bottom, $12 \mathrm{~cm}$ of fine gravel $(2-3 \mathrm{~cm}$ in diameter) in the middle, and $20 \mathrm{~cm}$ of coarse sand (1-2 cm in diameter) at the top. The MSL system was composed of soil mixture layers (SMLs $<2 \mathrm{~mm}$ diameter) and a permeable gravel layer (3-5 $\mathrm{cm}$ in diameter) with a height of $50 \mathrm{~cm}$. The SMLs were composed of mixed local garden soil (70\%), zeolite powder (12\%), coconut activated charcoal $(12 \%)$, and rice straw $(6 \%)$ based on a dry weight basis. The obtained mixture was packed into rectangular burlap/canvas bags $(40 \mathrm{~cm} \mathrm{~L} \times 15 \mathrm{~cm} \mathrm{~W} \times 5$ $\mathrm{cm} \mathrm{H).} \mathrm{Ten} \mathrm{bags} \mathrm{of} \mathrm{SMLs} \mathrm{were} \mathrm{arranged} \mathrm{into} \mathrm{four} \mathrm{layers} \mathrm{in} \mathrm{the} \mathrm{form} \mathrm{of} \mathrm{a} \mathrm{brick-like} \mathrm{wall} \mathrm{pattern,} \mathrm{and}$ alternating bags were filled with permeable river gravel layers (1-2 $\mathrm{cm}$ in diameter).

An IH system is a combination of MSL into a VF-CW system, and its structure was designed and installed comprising a 5-cm coarse gravel layer ( $3-5 \mathrm{~cm}$ in diameter) at the bottom, a 30 -cm permeable gravel layer (2-3 cm in diameter) with two lines of SMLs in between, and 15-cm coarse sand layer (1$2 \mathrm{~cm}$ in diameter) at the top. The average porosity of the filter in the VF-CW system, MSL system, and IH system was $41 \%, 36 \%$, and $37.5 \%$ respectively. Colocasia esculenta was planted in two rows on each filled bed of the VF-CW system and IH system, in which the plants were spaced in rows of $10 \mathrm{~cm}$. A perforated drainage pipe with an internal diameter of $25 \mathrm{~mm}$ with the holes pointing down was installed at the bottom of the three tanks and covered by a coarse gravel bed of diameter $3-5 \mathrm{~mm}$ to easily collect and convey the treated wastewater from the system to discharge. In addition, all three tanks were equipped with a vertical tube to control the water level in the tank. 


\subsection{Operational procedures and conditions}

The experimental procedures were the same in the three experimental systems. These systems were placed at room temperate (from 18 to $33{ }^{\circ} \mathrm{C}$ ) and run in parallel for more than 7 months, including a 3month start-up operation to establish proper growth in each tank, after which they were operated at design capacity for 4 months.

The start-up operation period of the systems was divided in two phases. In the first phase, the systems were operated at a constant HLR of approximately $66.67 \mathrm{~L} /\left(\mathrm{m}^{2} \cdot \mathrm{d}\right)$ for 5 weeks. Corresponding to operational weeks $1,2,3,4$, and 5 , the systems were fed with rice noodle wastewater diluted with tap water at the rates of $100 \%, 75 \%, 50 \%, 25 \%$, and $0 \%$ respectively. The observed results (e.g., plant growth parameters, the color of bubbles that appeared on the top surface of each tank, etc.) during the first 5 weeks indicated that the systems could achieve a stable operating level during week 4, which corresponded to $75 \%$ diluted rice noodle wastewater. The second phase prolonged about 6 weeks, which was from $6^{\text {th }}$ week to $11^{\text {th }}$ week and the systems were fed with rice noodle wastewater diluted to $25 \%$ with tap water at a HLR of $50 \mathrm{~L} /\left(\mathrm{m}^{2} \cdot \mathrm{d}\right)$. The dead and weakened plants in the VF-CW and IH systems were also replanted.

After the start-up period, the rice noodle wastewater was pumped intermittently into the three systems twice a day at 7:00 and 17:00 at an average inflow of $12 \mathrm{~L} / \mathrm{d}$ (giving a HLR of $50 \mathrm{~L} /\left(\mathrm{m}^{2} \cdot \mathrm{d}\right.$ )) during the 4 months of the experiment (August 14 to September 12), and the wastewater was waterlogged at $3 \mathrm{~cm}$ above the filter line. The influent wastewater was evenly distributed by horizontally perforated pipes that were installed on the top of each treatment tank. The hydraulic retention times (HRTs) of the VFCW, MSL, and IH systems were 3.3, 3.6, and 3.4 days, respectively. The treated wastewater from the three systems was manually drained prior to re-feeding wastewater to the systems. 


\subsection{Removal mechanisms}

The removal mechanisms and biochemical reactions are results of the interaction between multiple components in WWTS such as bacteria, filtration materials, plant, characteristics of influents, environmental parameters, operating conditions (hydraulic loading rate, influent fed regime, recirculation, organic carbon addition, etc.), etc. Each pollutant parameter may be removed by different mechanisms. For example, organic compounds of wastewater can be degraded aerobically and anaerobically by bacteria attached to plant underground organs (roots and rhizomes) and media area (Kadlec and Knight, 1996; Vymazal, 2005). However, nitrogen removal is quite complicated, including several pathways such as biological (e.g. ammonification, nitrification, denitrification, biomass assimilation, plant uptake), and physicochemical routes (i.e. ammonia volatilization, and adsorption) and others (i.e. anammox and canon processes) (Saeed and Sun, 2012). Whereas, the removal of fecal indicators happens by physical (e.g. filtration, sedimentation and sorption), chemical (e.g. oxidation), and biological factors (e.g. antimicrobial activity, predation and activity of lytic bacteria or viruses), in combination or alone. WWTS usually show both aerobic and anoxic conditions which depends on the depth and type of wetland (Nguyen et al., 2018). The abundant oxidant, electron donors (mainly organic matter and ammonia), are oxidized and this reduction of $\mathrm{O}_{2}$ to $\mathrm{H}_{2} \mathrm{O}$ is carried out by true aerobic microorganisms, and $\mathrm{CO}_{2}$ is evolved as a waste product. After oxygen is depleted, organisms capable of reducing $\mathrm{NO}_{3}^{-}, \mathrm{MnO}_{2}$ and $\mathrm{SO}_{4}^{2-}$ develop and other reactions might occur in response to the decrease in oxygen and the redox potential (Nguyen et al., 2018, Kadlec and Knight, 1996).

\subsection{Sampling and analyses}

Total 36 wastewater samples were collected every 3 days or weekly from the effluent of the treatment tanks and influent of the storage tank. They were analyzed immediately after sampling without filtering 
or pretreatment. The water quality parameters $\mathrm{BOD}_{5}(5220 \mathrm{D}), \mathrm{COD}_{\mathrm{Cr}}(5210 \mathrm{~B}), \mathrm{NO}_{3}-\mathrm{N}\left(4500 \mathrm{NO}_{3}-\mathrm{B}\right)$, $\mathrm{NH}_{4}-\mathrm{N}\left(4500-\mathrm{NH}_{3} \mathrm{~F}\right), \mathrm{PO}_{4}-\mathrm{P}(4500 \mathrm{P}-\mathrm{D})$, TSS (2540D), and Tcol (9221 B), were determined according to the standard methods (APHA/WEF/AWWA, 2005). Devices used to analyze the wastewater quality included water quality meter (Model: HQ40d, Hach Co., USA), spectrophotometer (Model: Carry 60 Agilent, USA), incubator (Model: TC 135S - Aqualytic, Germany), water bath (Model: WNB 22 Memmert, Germany), oven (Model: Won- 50: Daihan Scientific, Korean), colony counter (Model: ColonyStar - Funke Gerber, Germany), and Medical Clean Bench (SW-CJ-1EP, Airtech, China).

\subsection{Statistical analysis}

All statistical analyses were carried out using the R statistical environment (R Statistical Software Version 3.2.2). An analysis of variance (ANOVA) was used for the relationships between the treatment tanks and removal efficiencies, and a post-hoc test (Tukey's Honest Significant Difference (HSD)) was used for comparing the multiple means at a 95\% confidence level. Post-hoc tests determined which levels were causing these differences.

\section{Results and discussion}

\subsection{Wastewater characterization}

In general, the concentrations of contaminants in rice noodle wastewater were high, unstable, and varied such as the $\mathrm{COD}_{\mathrm{Cr}}, \mathrm{BOD}$, and total Kjeldahl nitrogen concentrations, which varied from 4,200 to $29,000 \mathrm{mg} / \mathrm{L}, 5,400$ to $23,200 \mathrm{mg} / \mathrm{L}$, and 68.70 to $198.00 \mathrm{mg} / \mathrm{L}$ respectively (Jijai and Siripatana, 2017; Nanta et al., 2018; Siripattanakul-Ratpukdi, 2012). The key characteristics of the raw rice noodle wastewater are summarized in Table 1. According to a survey conducted by the Vietnam Ministry of Natural Resources and Environment on wastewater from traditional noodle handicraft villages, the average concentrations of $\mathrm{COD}_{\mathrm{Cr}}$, $\mathrm{BOD}_{5}$, and Tcol for Cam Thach village were 3,550 mg/L, $500 \mathrm{mg} / \mathrm{L}$ 
and 11.000 MPN/100mL respectively (MONRE, 2008), in which, $\mathrm{COD}_{\mathrm{Cr}}$ and $\mathrm{BOD}_{5}$ were much higher compared to those of the wastewater used in this study (Table 1). This suggests that the septic tank contributed significantly to reduce the organic concentrations in the wastewater effluent from rice noodle manufacturing $\left(338.6 \pm 114.8 \mathrm{mg} / \mathrm{L} \mathrm{COD} \mathrm{Cr}_{\mathrm{r}}\right)$. However, nutrient concentrations remained relatively high in the effluent $\left(72.1 \pm 24.5 \mathrm{mg} / \mathrm{L} \mathrm{NH}_{4}-\mathrm{N}\right.$ and $\left.16.7 \pm 8.6 \mathrm{mg} / \mathrm{L} \mathrm{PO}_{4}-\mathrm{P}\right)$, which must be further treated before being reused or discharged legally into the environment.

\subsection{System performance}

\subsubsection{Organic matter removal}

The overall results obtained from the three WWTS are shown in Table 2. To compare the treatment efficiency of the units, an ANOVA and Tukey's HSD analysis were applied to identify the statistical differences between the units. The ANOVA analysis indicated that there was a statistically significant difference between the three systems $(\mathrm{p}<0.05, \mathrm{~F}=4.13)$, whereas Tukey's HSD analysis indicated only a significant difference between the IH system and MSL system in effluent concentrations of $\operatorname{COD}_{\mathrm{Cr}}(p<0.05)$ (Table 2). It suggests that other similar conditions such as plants and media materials in the MSL and IH systems may influence the efficiency of $\mathrm{COD}_{\mathrm{Cr}}$ removal. An indication of the difference was that the $\mathrm{COD}_{\mathrm{Cr}}$ effluent concentration of the IH system $(84.02 \pm 32.68 \mathrm{mg} / \mathrm{L})$ was much lower than that of the MSL system $(107.00 \pm 39.27 \mathrm{mg} / \mathrm{L})$. In addition, the substantial mass removal for $\mathrm{COD}_{\mathrm{Cr}}$ were noticed through the experimental systems with a mean of 11.58 to $12.73 \mathrm{~g} /\left(\mathrm{m}^{2} \cdot \mathrm{d}\right)$ (Table 2). These mass removal rates were lower than the results of the MSL system (Attanandana et al., 2000; Latrach et al., 2016) and higher than those of the VF-CW system (Wu et al., 2013). This difference may be explained because the height in MSL is usually larger and use better filter layers, while the plants in VF-CW are quite sensitive to high hydraulic rate and pollution load.

Table 2. The mean $\mathrm{COD}_{\mathrm{Cr}}$ effluent concentration, removal rate, and statistical analysis. 


\begin{tabular}{|c|c|c|c|}
\hline System & Effluent & Removal rate $\left(\mathrm{g} /\left(\mathrm{m}^{2} \cdot \mathrm{d}\right)\right)$ & $\mathrm{p}$ value for Tukey's method \\
\hline MSL system & $107.00 \pm 39.27$ & $11.58 \pm 5.36$ & MSL vs. VF-CW \\
\hline VF-CW system & $100.58 \pm 34.14$ & $11.90 \pm 5.62$ & MSL vs. IH \\
\hline IH system & $84.02 \pm 32.68$ & $12.73 \pm 5.27$ & VF-CW vs. IH \\
\hline $\mathrm{MSL}^{\mathrm{a}}$ & 57 & 21.9 & \\
\hline $\mathrm{MSL}^{\mathrm{b}}$ & 140 & 42.9 & \\
\hline $\mathrm{VF}-\mathrm{CW}{ }^{\mathrm{c}}$ & $7.2-75.5$ & $1.51-56.07$ & \\
\hline $\mathrm{VF}-\mathrm{CW} \mathrm{W}^{\mathrm{d}}$ & 19.7 & 10.9 & \\
\hline \multicolumn{4}{|c|}{${ }^{\mathrm{a}} \mathrm{MSL}$ for domestic water treatment (Latrach et al., 2016). } \\
\hline
\end{tabular}

The variation in $\mathrm{COD}_{\mathrm{Cr}}$ influent and effluent concentrations and the $\mathrm{COD}_{\mathrm{Cr}}$ removal efficiency of each system during operation of experiments for 113 days are illustrated in Figure 2. The experimental results showed that there was significant variation in influent $\mathrm{COD}_{\mathrm{Cr}}$ concentrations (high fluctuations in the $\mathrm{COD}_{\mathrm{Cr}}$ loading rate in the influent) throughout the experiment. However, the effluent $\mathrm{COD}_{\mathrm{Cr}}$ concentrations decreased substantially through all the systems with an average reduction of more than $66 \%$, which corresponded to $\mathrm{COD}_{\mathrm{Cr}}$ concentrations in the final effluent of less than $107 \mathrm{mg} / \mathrm{L}$, which were much lower than that of the standard for waterbody discharges in Vietnam (150 mg/L, Fig. 1a), Italia (DLgs 152/2006) (160 mg/L) (Ghimpusan et al., 2017), Malaysia (200 mg/L) (NRE, 2009) and European Community $(125 \mathrm{mg} / \mathrm{L})(\mathrm{EU}, 1991)$. The $\mathrm{COD}_{\mathrm{Cr}}$ removal percentage of the IH system (73.23\%) was higher and more stable than that of the MSL system (66\%) and VF-CW system $(67.42 \%)$ (Fig. 1c), which corresponded to their average $\mathrm{COD}_{\mathrm{Cr}}$ concentrations remaining in the effluent of $84.02 \mathrm{mg} / \mathrm{L}, 107.00 \mathrm{mg} / \mathrm{L}$, and $100.58 \mathrm{mg} / \mathrm{L}$ respectively. Conversely, previous studies conducted by Lu and co-workers (2015) and Luanmanee and co-workers (2001) concluded that the $\mathrm{COD}_{\mathrm{Cr}}$ reduction efficiency of the MSL system was higher than that of conventional filters or natural soil systems, such as sand filters and CWs. 
Some outliers suggested that the removal efficiencies of the VF-CW and MSL systems were not stable

(Fig. 1c). The higher $\mathrm{COD}_{\mathrm{Cr}}$ treatment efficiency achieved by the IH system was attributed to the different media layer configurations with high absorbability and porosity, which adsorbed organic pollutants in wastewater onto the media and provided good environmental conditions that allowed easy decomposition by organisms and plant uptake (Ávila et al., 2015; Marzo et al., 2018; Nguyen et al., 2018)
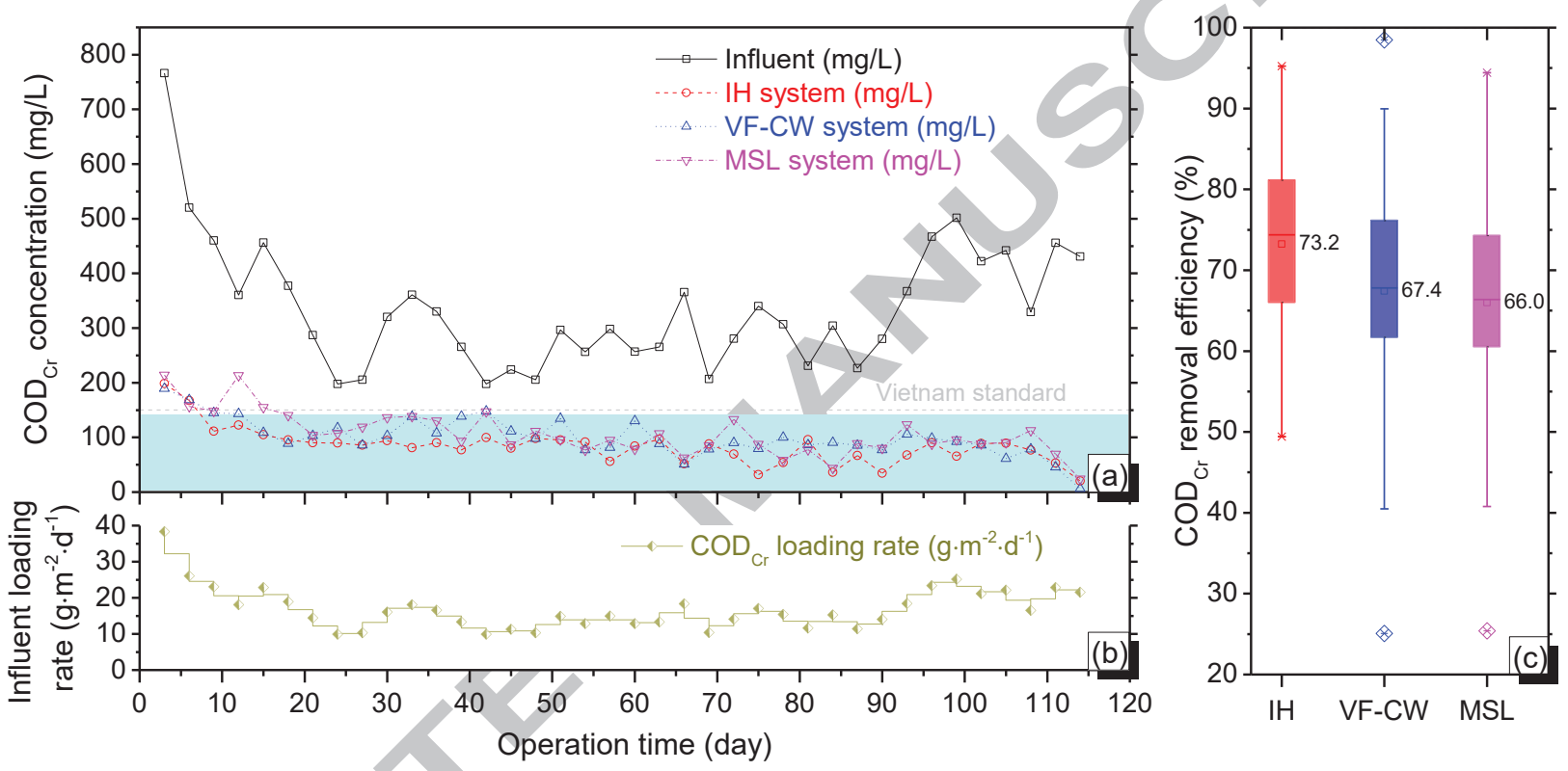

Figure 1. Temporal variations in $\mathrm{COD}_{\mathrm{Cr}}$ concentrations (a), influent $\mathrm{COD}_{\mathrm{Cr}}$ loading rate (b), and overall $\mathrm{COD}_{\mathrm{Cr}}$ removal efficiency (c) in each system during operation.

\subsubsection{Nutrients removal}

The results obtained (Fig. 2a) indicate that although the concentration of $\mathrm{NH}_{4}-\mathrm{N}$ in the final effluent of the IH system remained at approximately $35.93 \pm 20.01 \mathrm{mg} / \mathrm{L}$, which was slightly higher than that in the effluent of the MSL and VF-CW systems $(31.59 \pm 16.56 \mathrm{mg} / \mathrm{L}$ and $30.95 \pm 24.94 \mathrm{mg} / \mathrm{L}$, respectively). In general, these values did not differ significantly based on post-hoc analysis and ANOVA $(\mathrm{p}>0.05, \mathrm{~F}=0.51)$. Similarly, this trend occurred with $\mathrm{NH}_{4}-\mathrm{N}$ removal rates in these 
systems. This meant that the extent and process of removing $\mathrm{NH}_{4}-\mathrm{N}$ in the three systems were relatively similar. On the contrary, the effluent concentration of $\mathrm{NO}_{3}-\mathrm{N}$ increased slightly through all three tanks from $0.40 \pm 0.57 \mathrm{mg} / \mathrm{L}$ to $1.50 \pm 1.51 \mathrm{mg} / \mathrm{L}$ for MSL, $1.33 \pm 1.03 \mathrm{mg} / \mathrm{L}$ for VF-CW, and $1.66 \pm 1.63 \mathrm{mg} / \mathrm{L}$ for IH (Fig. 2b). It was expected because parallel processes occurred in the WWTS, including ammonium removal and nitrification, which were enhanced by intermittent water flow into the units through the perforated pipes. Nitrogen was reduced in these systems by the two main processes of nitrification and denitrification due to the simultaneous existence of aerobic and anaerobic conditions with various microbial abundances, which facilitated the conversion of $\mathrm{NH}_{4}-\mathrm{N}$ to $\mathrm{NO}_{3}-\mathrm{N}$ and nitrogen gas and the adsorption of $\mathrm{NH}_{4}-\mathrm{N}$. This occurred mainly in SMLs (including zeolite, soil, and charcoal) (Chen et al., 2009; Guan et al., 2012; Zhang et al., 2015).

In addition, Figure 3a shows that the $\mathrm{NH}_{4}-\mathrm{N}$ concentration in the effluent of the three systems was still higher compared to Vietnam's standard $(<10 \mathrm{mg} / \mathrm{L})$ and Italy's standard $(<15 \mathrm{mg} / \mathrm{L})$ (Ghimpusan et al., 2017). This could be ascribed to the high concentration of influents (average of $72.1 \pm 30.95 \mathrm{mg} / \mathrm{L}$ ) that was beyond the inherent capacity of these WWTS. However, throughout the operation, the average $\mathrm{NH}_{4}-\mathrm{N}$ removal efficiency of the VF-CW system was $60.64 \%$, which was higher than that obtained from the MSL system (53.1\%) and IH system (49.3\%) (Fig. 2d). These results were not in line with previous reports, that highlighted the nitrification and adsorption capacities of MSL in $\mathrm{NH}_{4}-\mathrm{N}$ reduction for treatment of municipal wastewater, domestic wastewater, and unsanitary landfill leachate as shown by Chen et al. (2009), Guan et al. (2012), Latrach et al. (2016), and Attanandana et al. (2000). The higher $\mathrm{NH}_{4}-\mathrm{N}$ removal efficiency reported in these studies (Chen et al., 2009; (50-70\%), Guan et al., 2012; (82.4\%), Latrach et al., 2016 (83\%), and Attanandana et al., 2000) (61.2\%)) could possibly be due to the characteristics of the material composition in MSL systems. It offers a number of advantages, such as larger porosity, high cation exchange and adsorption capacities, better oxygen 
diffusion, which could help to enhance the wastewater distribution, microbial growth rate and activity, and, as a consequence, an increase in the removal of $\mathrm{NH}_{4}-\mathrm{N}$.
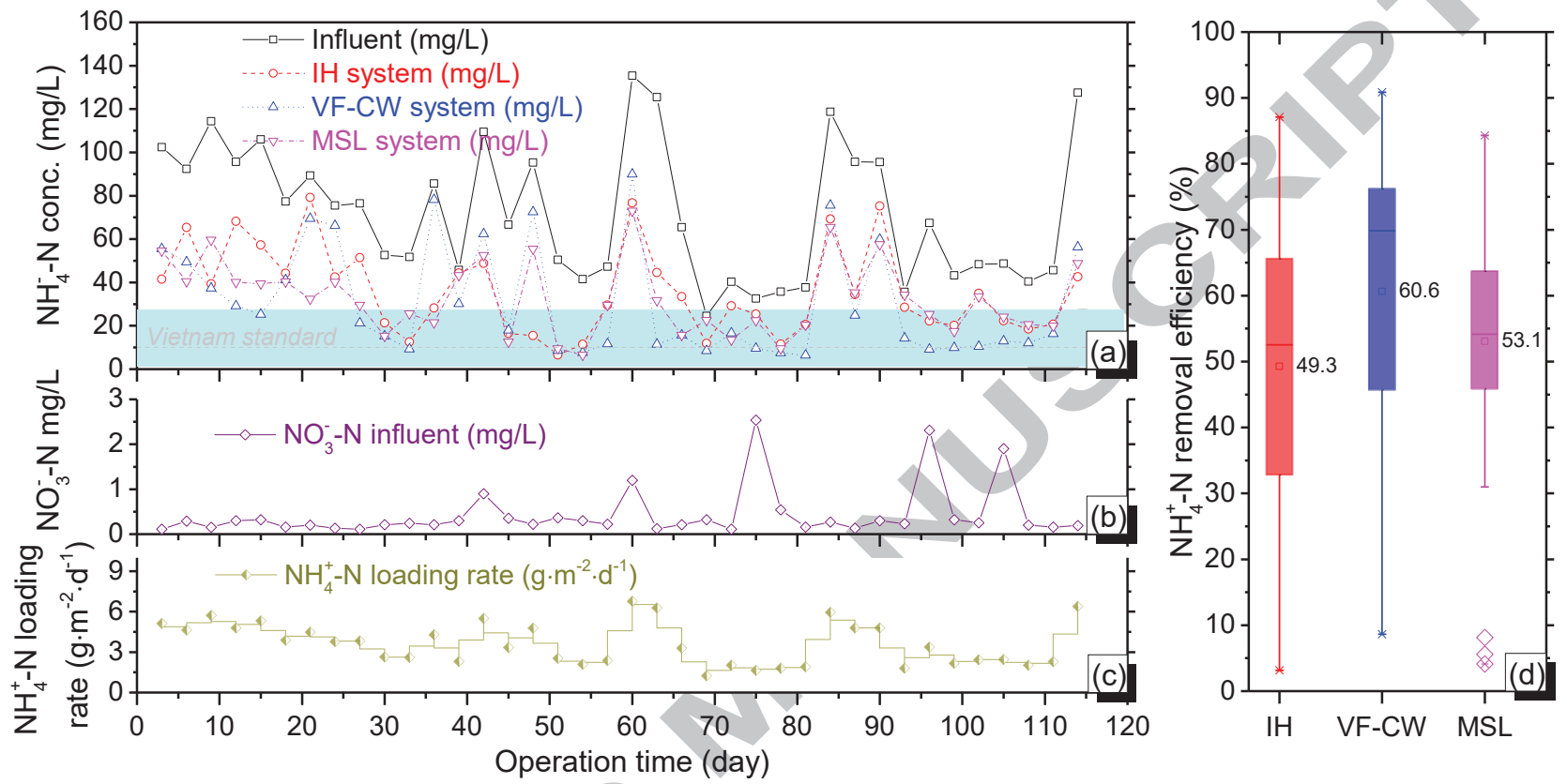

Figure 2. Temporal variation in concentrations of $\mathrm{NH}_{4}-\mathrm{N}$ in the influent and effluent. (a) Influent $\mathrm{NO}_{3}-$ $\mathrm{N}$ concentration. (b) Influent $\mathrm{NH}_{4}-\mathrm{N}$ loading rate. (c) Overall $\mathrm{NH}_{4}-\mathrm{N}$ removal efficiency. (d) IH, VF$\mathrm{CW}$ and MSL system during operation.

The $\mathrm{PO}_{4}-\mathrm{P}$ concentration in the influents and effluents and the $\mathrm{PO}_{4}-\mathrm{P}$ removal efficiency throughout the experiments are depicted in Fig. 3. These results showed that the average concentration of $\mathrm{PO}_{4}-\mathrm{P}$ remaining in the final effluent of the VF-CW system was high at $12.35 \pm 2.01 \mathrm{mg} / \mathrm{L}$, which was higher than that obtained in the final effluent of the IH and MSL systems at $7.26 \pm 1.99 \mathrm{mg} / \mathrm{L}$ and $8.92 \pm 1.63$ $\mathrm{mg} / \mathrm{L}$ respectively (while Vietnam and Malaysia's phosphorus discharge standard is $10 \mathrm{mg} / \mathrm{L}$ ). The $\mathrm{PO}_{4}-\mathrm{P}$ removal efficiencies in the VF-CW, IH, and MSL systems were $23.88 \%, 54.02 \%$, and $44.73 \%$ respectively, regardless of the significant fluctuation in influent concentration in the range of 8.56 to $24.2 \mathrm{mg} / \mathrm{L}$ with a $\mathrm{PO}_{4}-\mathrm{P}$ loading rate in the range of 0.43 to $1.21 \mathrm{~g} /\left(\mathrm{m}^{2} \cdot \mathrm{d}\right)$. The higher removal 
efficiencies found for $\mathrm{PO}_{4}-\mathrm{P}$ in the MSL $(44.7 \%$; $<<0.0005)$ and $\mathrm{IH}(54 \% ; \mathrm{p}<0.005$,) systems may be due to the adsorption capacity in the SMLs of the MSL system, in which phosphorus could be adsorbed on the $\mathrm{Al}$ and $\mathrm{Fe}$ hydroxides in the soil (Chen et al., 2009). In contrast, the mechanism for reducing $\mathrm{PO}_{4}-\mathrm{P}$ in the VF-CW system $(23.9 \%, \mathrm{p}<0.0005)$ was limited may be because the gravel substrate was not capable of binding phosphorous (Arias and Brix, 2005; Brix et al., 2001). The results of the $\mathrm{PO}_{4}-\mathrm{P}$ reduction obtained in this study were consistent with the experimental data of a VF system acquired by O'Hogain (2003) (39\%) and lower than those of MSL systems studied by Latrach et al. (2016) (84\%) and Masunaga et al. (2007) (56-85\%). Moreover, the results of the statistical test indicated that the differences between the effluents of the three systems were statistically significant ( $p$ $<0.005, \mathrm{~F}=70.1$ ). It means that the SMLs in the IH and MSL systems contributed greatly to the $\mathrm{PO}_{4}-\mathrm{P}$ reduction in the experimental units.
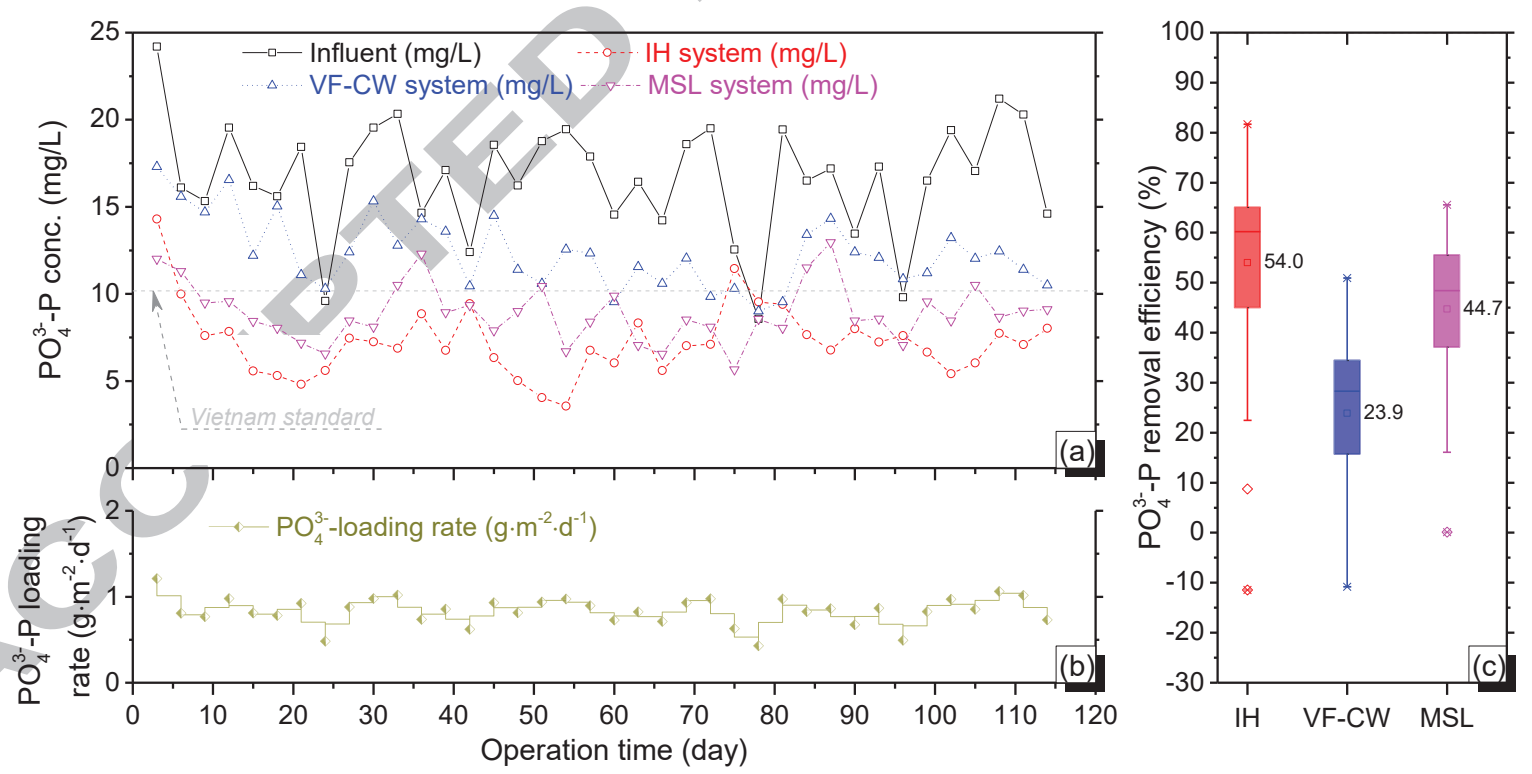

Figure 3. Temporal variations in $\mathrm{PO}_{4}-\mathrm{P}$ concentrations in influent and effluent. (a) Influent $\mathrm{PO}_{4}-\mathrm{P}$ loading rate (b) Overall $\mathrm{PO}_{4}$-P removal efficiency. (c) IH, VF-CW and MSL system during operation. 


\subsubsection{Total suspended solids and total coliform removals}

During the operation of the systems, the TSS and Tcol concentrations in the influent and effluent of each system were measured (Fig. 4). The fluctuation in TSS concentrations in the influent ranged from 37.60 to $132.00 \mathrm{mg} / \mathrm{L}$ with an average value of $87.27 \pm 21.41 \mathrm{mg} / \mathrm{L}$ (Fig. 4a, e). Despite the large variations in TSS in the influent, the TSS removal efficiencies of the VF-CW, MSL, and IH systems were consistently stable and fairly high, and were $75 \pm 16 \%, 80 \pm 11 \%$, and $72 \pm 15 \%$ respectively. It corresponded to the average concentrations of TSS in the effluent of approximately $20.76 \pm 9.52 \mathrm{mg} / \mathrm{L}$, $15.85 \pm 7.16 \mathrm{mg} / \mathrm{L}$, and $24.11 \pm 12.76 \mathrm{mg} / \mathrm{L}$ respectively. These effluent concentrations were lower than the discharge limit of Vietnam and EU's standard for TSS of less than $150 \mathrm{mg} / \mathrm{L}$ and $60 \mathrm{mg} / \mathrm{L}$ respectively (Fig. 4a, e). In addition, post-hoc analysis and ANOVA test revealed that the TSS effluents did not differ significantly between the three systems $(F=0.55, \mathrm{p}>0.05)$.

The average Tcol inactivation efficiencies of the VF-CW, MSL, and IH systems were not high, with values of 4.57, 4.54, and $4.78 \log$ MPN/100 mL respectively, which corresponded to the average coliform concentrations remaining in the effluent of $2.63 \mathrm{E}+04 \pm 1.11 \mathrm{E}+04 \mathrm{MPN} / 100 \mathrm{~mL}, 3.61 \mathrm{E}+04 \pm$ 0.82E+04 MPN/100 mL, and 9.22E+03 $\pm 3.48 \mathrm{E}+03 \mathrm{MPN} / 100 \mathrm{~mL}$ respectively (Fig. 4c, d, f). The remaining coliform concentrations were still at high levels that exceeded the allowable discharge standard of Vietnam (5,000 MPN/100 mL). This was also reasonable because these systems only used biological methods. Thus, to achieve more effective disinfection, the further combination of other treatment techniques is encouraged, such as a tertiary treatment. Therefore, these systems are suitable for TSS reduction rather than coliform treatment, and the highest TSS removal efficiency was achieved in the MSL system. 


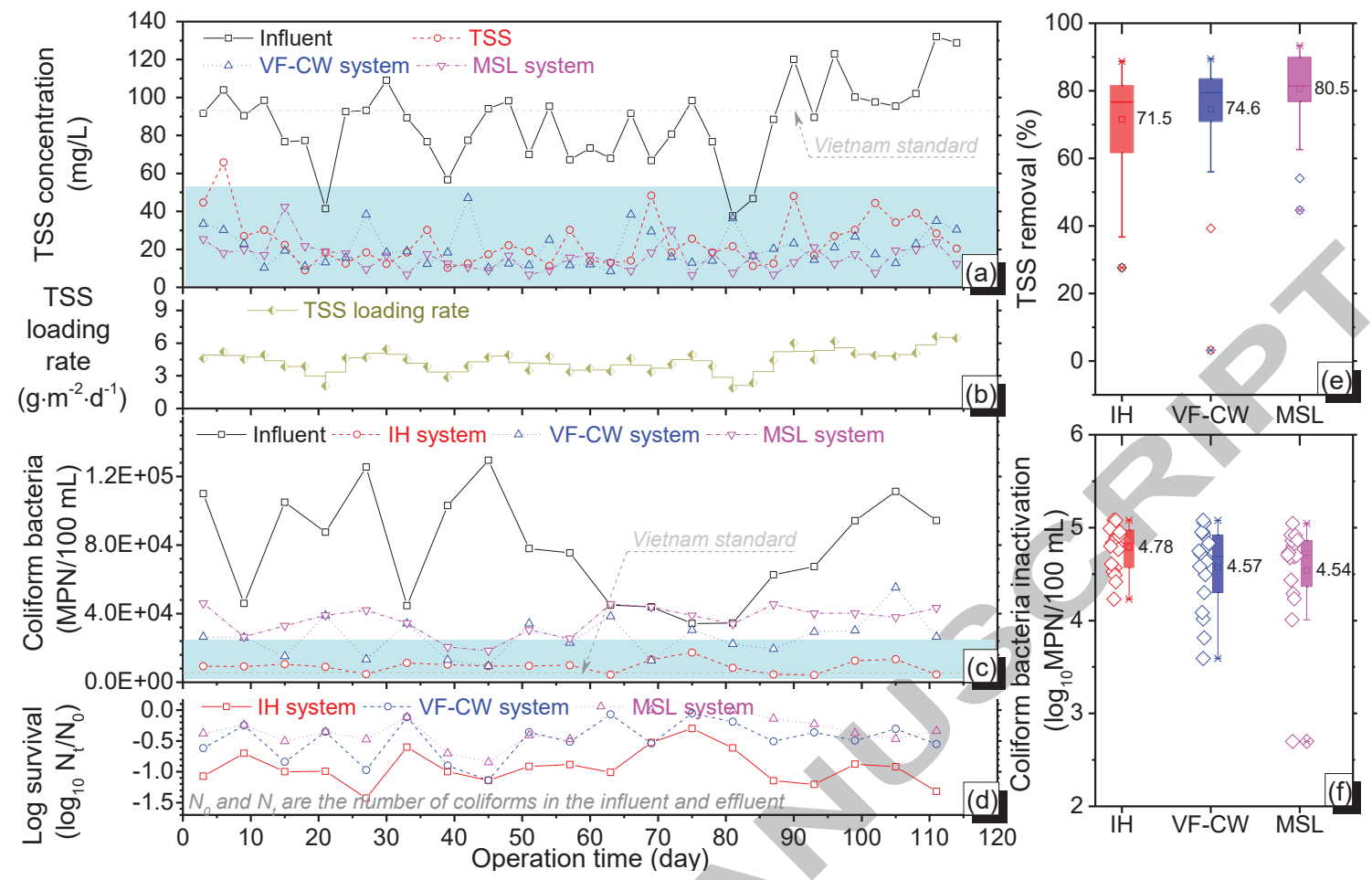

Figure 4. Temporal variations in total suspended solids (TSS) and total coliform (Tcol) concentrations in influent and effluent and their overall removal efficiency in each system during operation.

\subsection{Correlations between parameters}

Three main important parameters, namely $\mathrm{COD}_{\mathrm{Cr}}, \mathrm{NH}_{4}-\mathrm{N}$, and $\mathrm{PO}_{4}-\mathrm{P}$, were monitored and further evaluated by analyzing the correlation between variables of the initial loading rate and removal loading rate or removal efficiency (organics and nutrients removal) during the operation of the systems, which could explain the relationship and influence between these parameters as well as predict the output of these systems.

The linear relationships between the outputs in terms of effluent quality, removal rates, and influent loading rates for $\mathrm{COD}_{\mathrm{Cr}}$ and $\mathrm{NH}_{4}-\mathrm{N}$ are presented in Fig. 5. The results indicate that there was a high correlation between removal loading rate $\left(\mathrm{L}_{\mathrm{r}}\right)$ and influent mass loading rate $\left(\mathrm{L}_{\mathrm{i}}\right)$ in the three systems, with a high coefficient of determination $\left(\mathrm{R}^{2}\right)$ that varied from 0.88 to $0.92(\mathrm{p}<0.05)$ (Fig. 6a). This 
confirmed that the three equations in the plot could apply for predicting the output of systems or designing a new system. In addition, the correlations between effluent $\mathrm{COD}_{\mathrm{Cr}}$ and $\mathrm{L}_{\mathrm{i}}$ were relatively low (Fig. 5b), in which $\mathrm{R}^{2}$ ranged from $0.02-0.15$, and were not statistically significant compared with the data obtained in the VF-CW system. It seemed that the $\mathrm{COD}_{\mathrm{Cr}}$ concentration in the effluent was not influenced by $\mathrm{L}_{\mathrm{i}}$, and their correlation in the systems of this research did not follow first order linear equations.
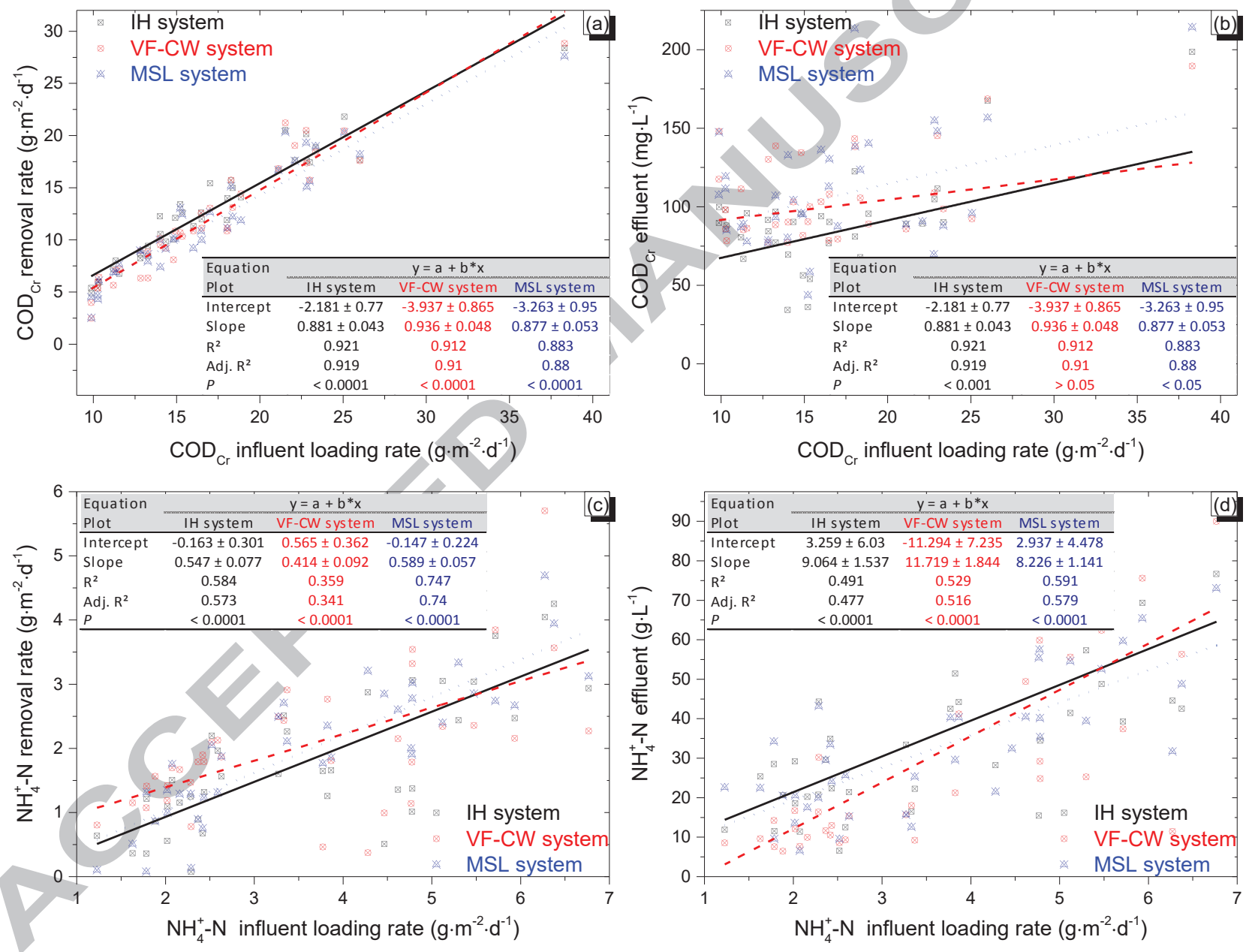

Figure 6. Correlations between $L_{i}, L_{r}$, and effluent concentrations of $\mathrm{COD}_{\mathrm{Cr}}$ and $\mathrm{NH}_{4}-\mathrm{N}$ in each system. 
For $\mathrm{NH}_{4}-\mathrm{N}$, the relationship between $\mathrm{NH}_{4}-\mathrm{N}$ removal rate, $\mathrm{NH}_{4}-\mathrm{N}$ concentration in the effluent, and $\mathrm{NH}_{4}-\mathrm{N}$ influent loading rate was statistically significant $(\mathrm{p}<0.0001)$ (Fig. 5c, d). Nevertheless, only the $\mathrm{R}^{2}$ values above 0.5 were acceptable for the linear regression (Hijosa-Valsero et al., 2011). The correlations between $\mathrm{NH}_{4}-\mathrm{N}$ removal rate and $\mathrm{NH}_{4}-\mathrm{N}$ influent loading rate (Fig. 5c) and those between $\mathrm{NH}_{4}-\mathrm{N}$ concentration in the effluent and $\mathrm{NH}_{4}-\mathrm{N}$ influent loading rate (Fig. 5d) in the MSL system were clearer than those obtained in the IH and VF-CW systems. Weak relationships between $\mathrm{L}_{\mathrm{r}}$ and $\mathrm{L}_{\mathrm{i}}$ and between $\mathrm{L}_{\mathrm{i}}$ and the effluent $\mathrm{NH}_{4}-\mathrm{N}$ were observed. Therefore, they were not very meaningful in the analysis of the linear regression. In addition, the results of the correlation analysis for $\mathrm{PO}_{4}-\mathrm{P}$ indicated that there was no proof to reject the null hypothesis $(p>0.05)$ and suggested that the relationships between $\mathrm{L}_{\mathrm{i}}$ and $\mathrm{L}_{\mathrm{r}}$ and between $\mathrm{L}_{\mathrm{i}}$ and effluent $\mathrm{PO}_{4}-\mathrm{P}$ were not statistically significant. This mean that the $\mathrm{PO}_{4}-\mathrm{P}$ concentration in the effluent might not be predictable through influent loading rates.

In summary, the results showed that these technologies were suitable for the removal of organic matter and SS and could meet the regulation limits of Vietnam. However, the nutrients and Tcol concentrations were reduced modestly through all three treatment units, with removal rates of $49.3 \%$ to $60.6 \%$ for $\mathrm{NH}_{4}-\mathrm{N}$ and $23.9 \%$ to $54.0 \%$ for $\mathrm{PO}_{4}-\mathrm{P}$. Consequently, a further study with two stages of tank might be required in the future. The IH system obtained the highest reduction with an average value of $73.2 \%$ for $\mathrm{COD}_{\mathrm{Cr}}, 54.0 \%$ for $\mathrm{PO}_{4}-\mathrm{P}$, and $4.78 \log \mathrm{MPN} / 100 \mathrm{~mL}$ inactivation for Tcol, while the highest removal efficiencies of $\mathrm{NH}_{4}-\mathrm{N}(60.64 \%)$ and TSS $(80.49 \%)$ were achieved in the VF-CW and MSL systems respectively. Generally, the IH system is recommended for RNWWT due to higher treatment performance in comparison with the VF-CW and MSL systems. Moreover, the system with two stages of IH and a kind of WWTS such as the polishing pond, free water surface constructed wetland, which support to treat the nutrients and Tcol, might be needed for application of RNWWT to fulfill strictly the effluent regulations. Finally, this study also offers an additional choice and allow 
greater versatility in choice of technology, design, installation, and operation to treat rice noddle wastewater.

\section{Conclusions}

Three RNWWT systems using natural physical, biochemical, and microbiological processes were parallel operated in a tropical climate to compare and evaluate their treatment performance. The results showed that these technologies are suitable for the removal of organic matter and SS, and could meet the regulation limits of Vietnam. However, the nutrients and Tcol concentrations were reduced modestly through all three treatment units, further treatment might be required. Generally, the IH system is recommended for RNWWT due to higher treatment performance in comparison with the VFCW and MSL systems.

\section{Acknowledgments}

This research was supported in part by the Ministry of Environment as part of the Advanced Technology Program for Environmental Industry (2016000140004) and The Vietnam's National Foundation for Science and Technology Development (NAFOSTED). The Vietnam Ministry of Environment, Kyonggi University, and Vietnam National University are acknowledged for the Ph.D. scholarship support provided to X.C. Nguyen.

\section{References}

1. APHA/WEF/AWWA. 2005. Standard methods for the examination of water \& wastewater, centennial edition. 21 ed, American Public Health Association, the American Water Works Association, and the Water Environment Federation. Washington DC, USA.

2. Arias, C., Brix, H. 2005. Phosphorus Removal in Constructed Wetlands: Can Suitable Alternative Media Be Identified?. Water Science \& Technology, 51(9), 267-73.

3. Attanandana, T., Saitthiti, B., Thongpae, S., Kritapirom, S., Luanmanee, S., Wakatsuki, T. 2000. Multimedia-layering system for food service wastewater treatment. Ecological Engineering, 15(1), 133-138.

4. Ávila, C., Bayona, J.M., Martín, I., Salas, J.J., García, J. 2015. Emerging organic contaminant removal in a full-scale hybrid constructed wetland system for wastewater treatment and reuse. Ecological Engineering, 80, 108-116. 
5. Bonanno, G., Vymazal, J., Cirelli, G.L. 2018. Translocation, accumulation and bioindication of trace elements in wetland plants. Science of The Total Environment, 631-632, 252-261.

6. Brix, H., Arias, C., del Bubba, M. 2001. Media Selection for Sustainable Phosphorus Removal in Subsurface Flow Constructed Wetlands. Water Science \& Technology, 44(11-12), 47-54.

7. Chang, J.J., Liang, K., Wu, S.Q., Zhang, S.H., Liang, W. 2015. Comparative evaluations of organic matters and nitrogen removal capacities of integrated vertical-flow constructed wetlands: Domestic and nitrified wastewater treatment. J Environ Sci Health A Tox Hazard Subst Environ Eng, 50(7), 757-66.

8. Chen, X., Luo, A.C., Sato, K., Wakatsuki, T., Masunaga, T. 2009. An introduction of a multi-soil-layering system: a novel green technology for wastewater treatment in rural areas. Water and Environment Journal, 23(4), 255-262.

9. Corbella, C., Puigagut, J., Garfí, M. 2017. Life cycle assessment of constructed wetland systems for wastewater treatment coupled with microbial fuel cells. Science of The Total Environment, 584-585, 355362.

10. EU. 1991. Council Directive 91/271/EEC of 21 May 1991 Concerning Urban Waste-Water Treatment, (Ed.) E. Council. Brussels.

11. Ghimpusan, M., Nechifor, G., Nechifor, A.C., Dima, S.O., Passeri, P. 2017. Case studies on the physicalchemical parameters' variation during three different purification approaches destined to treat wastewaters from food industry. J Environ Manage, 203(Pt 2), 811-816.

12. Guan, J., Zhang, Y., Zhong, C.-N., Huang, X.-F., Fu, J., Zhao, D. 2015. Effect of operating factors on the contaminants removal of a soil filter: multi-soil-layering system. Environ Earth Sci, 71(3), 2679-2686.

13. Guan, Y., X, C., S, Z., AC, L. 2012. Performance of multisoil-layering system (MSL) treating leachate from rural unsanitary landfills. Sci Total Environ, 420(15), 183-190.

14. Guan, Y., Zhou, J., Fu, X., Zhao, Y., Luo, A., Xu, J., Fu, J., Zhao, D. 2018. Effects of long-lasting nitrogen and organic shock loadings on an engineered biofilter treating matured landfill leachate. Journal of Hazardous Materials, 360, 536-543.

15. Hijosa-Valsero, M., Sidrach-Cardona, R., Martín-Villacorta, J., Valsero-Blanco, M.C., Bayona, J.M., Bécares, E. 2011. Statistical modelling of organic matter and emerging pollutants removal in constructed wetlands. Bioresour. Technol., 102(8), 4981-4988.

16. Ho, C.-C., Wang, P.-H. 2015. Efficiency of a Multi-Soil-Layering System on Wastewater Treatment Using Environment-Friendly Filter Materials. International Journal of Environmental Research and Public Health, 12(3), 3362-3380.

17. Jia, L., Wang, R., Feng, L., Zhou, X., Lv, J., Wu, H. 2018. Intensified nitrogen removal in intermittentlyaerated vertical flow constructed wetlands with agricultural biomass: Effect of influent $\mathrm{C} / \mathrm{N}$ ratios. Chemical Engineering Journal, 345, 22-30.

18. Jijai, S., Siripatana, C. 2017. Kinetic Model of Biogas Production from Co-digestion of Thai Rice Noodle Wastewater (Khanomjeen) with Chicken Manure. Energy Procedia, 138, 386-392.

19. Kadlec, R.H., Knight, R.L. 1996. Treatment wetlands. Lewis Publishers, Boca Raton, FL.

20. Karmee, S.K. 2018. Noodle waste based biorefinery: an approach to address fuel, waste management and sustainability. Biofuels, 9(3), 395-404.

21. Koottatep, T., Suksiri, P., Pussayanavin, T., Polprasert, C. 2018. Development of a Novel Multi-soil Layer Constructed Wetland Treating Septic Tank Effluent with Emphasis on Organic and Ammonia Removals. Water, Air, \& Soil Pollution, 229, 229-258.

22. Latrach, L., Ouazzani, N., Hejjaj, A., Mahi, M., Masunaga, T., Mandi, L. 2018. Two-stage vertical flow multi-soil-layering (MSL) technology for efficient removal of coliforms and human pathogens from domestic wastewater in rural areas under arid climate. International Journal of Hygiene and Environmental Health, 221(1), 64-80. 
23. Latrach, L., Ouazzani, N., Masunaga, T., Hejjaj, A., Bouhoum, K., Mahi, M., Mandi, L. 2016. Domestic wastewater disinfection by combined treatment using multi-soil-layering system and sand filters (MSLSF): A laboratory pilot study. Ecological Engineering, 91, 294-301.

24. Li, M., Wu, H., Zhang, J., Ngo, H.H., Guo, W., Kong, Q. 2017. Nitrogen removal and nitrous oxide emission in surface flow constructed wetlands for treating sewage treatment plant effluent: Effect of C/N ratios. Bioresource Technology, 240, 157-164.

25. Licciardello, F., Milani, M., Consoli, S., Pappalardo, N., Barbagallo, S., Cirelli, G. 2018. Wastewater tertiary treatment options to match reuse standards in agriculture. Agricultural Water Management, 210, 232242.

26. Lu, S., Pei, L., Bai, X. 2015. Study on method of domestic wastewater treatment through new-type multilayer artificial wetland. International Journal of Hydrogen Energy, 40(34), 11207-11214.

27. Luanmanee, S., Attanandana, T., Masunaga, T., Wakatsuki, T. 2001. The efficiency of a multi-soil-layering system on domestic wastewater treatment during the ninth and tenth years of operation. Ecological Engineering, 18(2), 185-199.

28. Luo, W., Yang, C., He, H., Zeng, G., Yan, S., Cheng, Y. 2014. Novel two-stage vertical flow biofilter system for efficient treatment of decentralized domestic wastewater. Ecological Engineering, 64, 415-423.

29. Marzo, A., Ventura, D., Cirelli, G.L., Aiello, R., Vanella, D., Rapisarda, R., Barbagallo, S., Consoli, S. 2018. Hydraulic reliability of a horizontal wetland for wastewater treatment in Sicily. Science of The Total Environment, 636, 94-106.

30. Masunaga, T., Sato, K., Mori, J., Shirahama, M., Kudo, H., Wakatsuki, T. 2007. Characteristics of wastewater treatment using a multi-soil-layering system in relation to wastewater contamination levels and hydraulic loading rates: Original article.

31. MONRE. 2008. National state of environment 2008 - Vietnam craft village invironment. Ministry of Natural Resources and Environment.

32. Nanta, P., Kasemwong, K., Skolpap, W. 2018. Isotherm and kinetic modeling on superparamagnetic nanoparticles adsorption of polysaccharide. Journal of Environmental Chemical Engineering, 6(1), 794802.

33. Nguyen, X.C., Chang, S.W., Nguyen, T.L., Ngo, H.H., Kumar, G., Banu, J.R., Vu, M.C., Le, H.S., Nguyen, D.D. 2018. A hybrid constructed wetland for organic-material and nutrient removal from sewage: Process performance and multi-kinetic models. Journal of Environmental Management, 222, 378-384.

34. NRE. 2009. Environmental Quality (Sewage) Regulations. in: PU(A) 432/2009, (Ed.) M.o.N.R. Environment. Malaysia.

35. O'Hogain, S. 2003. The design, operation and performance of a municipal hybrid reed bed treatment system. Water Science \& Technology, 5(48), 119-126.

36. Saeed, T., Sun, G. 2012. A review on nitrogen and organics removal mechanisms in subsurface flow constructed wetlands: dependency on environmental parameters, operating conditions and supporting media. J Environ Manage, 112, 429-48.

37. Sgroi, M., Pelissari, C., Roccaro, P., Sezerino, P.H., García, J., Vagliasindi, F.G.A., Ávila, C. 2018. Removal of organic carbon, nitrogen, emerging contaminants and fluorescing organic matter in different constructed wetland configurations. Chemical Engineering Journal, 332, 619-627.

38. Shen, J., Huang, G., An, C., Song, P., Xin, X., Yao, Y., Zheng, R. 2018. Biophysiological and factorial analyses in the treatment of rural domestic wastewater using multi-soil-layering systems. Journal of Environmental Management, 226, 83-94.

39. Siripattanakul-Ratpukdi, S. 2012. Ethanol production potential from fermented rice noodle wastewater treatment using entrapped yeast cell sequencing batch reactor. Applied Water Science, 2(1), 47-53. 
40. Song, P., Huang, G., An, C., Shen, J., Zhang, P., Chen, X., Shen, J., Yao, Y., Zheng, R., Sun, C. 2018. Treatment of rural domestic wastewater using multi-soil-layering systems: Performance evaluation, factorial analysis and numerical modeling. Science of The Total Environment, 644, 536-546.

41. Suwan, D., Chitapornpan, S., Honda, R., Chiemchaisri, W., Chiemchaisri, C. 2014. Conversion of Organic Carbon in Food Processing Wastewater to Photosynthetic Biomass in Photo-bioreactors Using Different Light Sources. Environmental Engineering Research, 19(3), 293-298.

42. Tang, J., Wang, X.C., Hu, Y., Pu, Y., Huang, J., Ngo, H.H., Zeng, Y., Li, Y. 2019. Nutrients removal performance and sludge properties using anaerobic fermentation slurry from food waste as an external carbon source for wastewater treatment. Bioresource Technology, 271, 125-135.

43. Uggetti, E., Hughes-Riley, T., Morris, R.H., Newton, M.I., Trabi, C.L., Hawes, P., Puigagut, J., García, J. 2016. Intermittent aeration to improve wastewater treatment efficiency in pilot-scale constructed wetland. Science of The Total Environment, 559, 212-217.

44. Valipour, A., Ahn, Y.-H. 2015. Constructed wetlands as sustainable ecotechnologies in decentralization practices: a review. Environmental Science and Pollution Research, 23(1), 180-197.

45. Vo, T.-D.-H., Bui, X.-T., Nguyen, D.-D., Nguyen, V.-T., Ngo, H.-H., Guo, W., Nguyen, P.-D., Nguyen, C.-N., Lin, C. 2018. Wastewater treatment and biomass growth of eight plants for shallow bed wetland roofs. Bioresource Technology, 247, 992-998.

46. Vymazal, J. 2005. Horizontal sub-surface flow and hybrid constructed wetlands systems for wastewater treatment. Ecol Eng, 25(5), 478-490.

47. Wei, C.-j., Wu, W.-z. 2018. Performance of single-pass and by-pass multi-step multi-soil-layering systems for low-(C/N)-ratio polluted river water treatment. Chemosphere, 206, 579-586.

48. Wu, S.-q., Chang, J.-j., Dai, Y., Wu, Z.-b., Liang, W. 2013. Treatment performance and microorganism community structure of integrated vertical-flow constructed wetland plots for domestic wastewater. Environmental Science and Pollution Research, 20(6), 3789-3798.

49. Wu, S.-q., Zhang, J., Ngo, H.H., Guo, W., Hu, Z., Liang, S., Fan, J., Liu, H. 2015. A review on the sustainability of constructed wetlands for wastewater treatment: Design and operation. Bioresource Technology, 175, 594-601.

50. Zhang, Y., Cheng, Y., Yang, C., Luo, W., Zeng, G., Lu, L. 2015. Performance of system consisting of vertical flow trickling filter and horizontal flow multi-soil-layering reactor for treatment of rural wastewater. Bioresource Technology, 193, 424-432. 


\section{Graphical abstract}

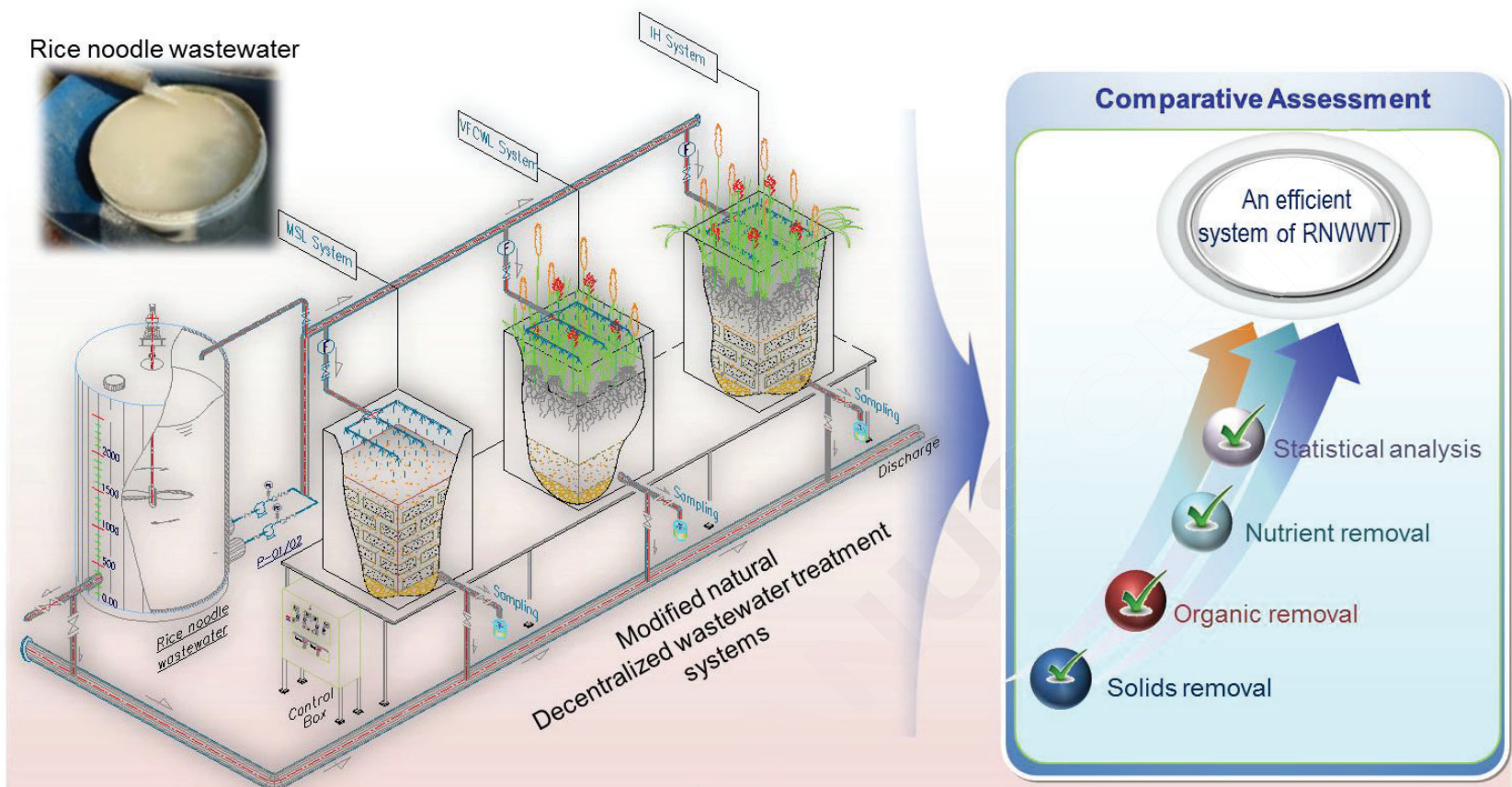

